\title{
The Study of Influence of Acid Catalysts Nature \\ on the Composition of Products \\ of Pine Wood Hemicelluloses Hydrolysis
}

\author{
Olga V. Yatsenkova, \\ Andrei M. Skripnikov, Svetlana A. Kozlova, \\ Natalia M. Ivanchenko and Boris N. Kuznetsov* \\ Institute of Chemistry and Chemical Technology SB RAS \\ FRC "Krasnoyarsk Science Center SB RAS" \\ 50/24 Akademgorodok, Krasnoyarsk, 660036, Russia
}

Received 02.02.2018, received in revised form 16.02.2018, accepted 04.03.2018

The processes of catalytic hydrolysis of hemicelluloses of pine wood at temperatures of $100-150^{\circ} \mathrm{C}$ were studied. The dissolved mineral acids $\mathrm{H}_{2} \mathrm{SO}_{4}$ and $\mathrm{HCl}$, as well as the solid acid catalysts Amberlyst-15, acid-modified SBA-15 and Sibunit-4 were used as the hydrolysis catalysts.

It was established that the maximum yield of monosaccharides $(96,0 \% \mathrm{wt}$. from the initial content of hemicelluloses in pine wood) is achieved at temperature of $100{ }^{\circ} \mathrm{C}$ in the presence of catalyst $2 \% \mathrm{wt}$. $\mathrm{HCl}$ with a hydrolysis time of $4 \mathrm{~h}$. The yield is reduced in the series of catalysts: $\mathrm{HCl}\left(100^{\circ} \mathrm{C}\right)>\mathrm{SBA}-15$ $\left(150^{\circ} \mathrm{C}\right)>$ Amberlyst $-15\left(150^{\circ} \mathrm{C}\right)>\mathrm{H}_{2} \mathrm{SO}_{4}\left(100^{\circ} \mathrm{C}\right)>\operatorname{Sibunit}-4\left(150^{\circ} \mathrm{C}\right)>$ without catalyst $\left(150^{\circ} \mathrm{C}\right)$. The lignocellulosic products formed during the hydrolysis of pine wood contain $51.0-55.5 \% \mathrm{wt}$. of cellulose, 29.2 - $36.7 \% \mathrm{wt}$. of lignin and 1.8 to $11.7 \% \mathrm{wt}$. of hemicelluloses.

The composition and structure of soluble and solid products of acid hydrolysis of pine wood are studied by gas chromatography, X-ray diffraction and chemical methods.

Keywords: pine wood, $\mathrm{H}_{2} \mathrm{SO}_{4}, \mathrm{HCl}$ catalysts, solid acid catalysts, hydrolysis, products, composition.

Citation: Yatsenkova O.V., Skripnikov A.M., Kozlova S.A., Ivanchenko N.M., Kuznetsov B.N. The study of influence of acid catalysts nature on the composition of products of pine wood hemicelluloses hydrolysis, J. Sib. Fed. Univ. Chem., 2018, 11(1), 42-55. DOI: 10.17516/1998-2836-0057.

(C) Siberian Federal University. All rights reserved

* Corresponding author E-mail address: yatsenkova@icct.ru 


\title{
Изучение влияния природы кислотных катализаторов \\ на состав продуктов гидролиза \\ гемицеллюлоз древесины сосны
}

\author{
О.В. Яценкова, А.М. Скрипников, \\ С.А. Козлова, Н.М. Иванченко, Б.Н. Кузнецов \\ Институт химии и химической технологии СО РАН \\ ФИЦ «Красноярский научный цуентр СО РАН» \\ Россия, 660036, Красноярск, Академгородок, 50/24
}

\begin{abstract}
Изучены прочессы каталитического гидролиза гемичеллюлоз древесины сосны при температурах $100-150^{\circ} \mathrm{C}$. В качестве катализаторов гидролиза использовали растворенные минеральные кислоты $\mathrm{H}_{2} \mathrm{SO}_{4}$ и $\mathrm{HCl}$, а также твердые кислотные катализаторы Amberlyst-15, кислотномодифицированные SBA-15 и Сибунит-4.

Установлено, что максимальный выход моносахаров (96,0 \% мас. от исходного содержания гемицеллюлоз в древесине сосны) достигается при температуре $100{ }^{\circ} \mathrm{C}$ в присутствии катализатора 2 \% мас. $\mathrm{HCl}$ при продолжительности гидролиза 4 ч и снижается в ряду катализаторов: $\mathrm{HCl}\left(100{ }^{\circ} \mathrm{C}\right)>\mathrm{SBA}-15\left(150{ }^{\circ} \mathrm{C}\right)>$ Amberlyst-15 $\left(150{ }^{\circ} \mathrm{C}\right)>\mathrm{H}_{2} \mathrm{SO}_{4}\left(100{ }^{\circ} \mathrm{C}\right)>$ Сибунит $-4\left(150^{\circ} \mathrm{C}\right)>$ без катализатора $\left(150^{\circ} \mathrm{C}\right)$.

Лигночеллюлозные продукты, образуюшиеся при гидролизе древесины, содержат 51,0-55,5 \% мас. иеллюлозы, 29,2-36,7 \% мас. лигнина и 1,8-11,7 \% мас. гемицеллюлоз.

Методамигазовойхроматографии, ИКС ихимическими изучен состав и строение растворимых и твердых продуктов кислотного гидролиза древесины сосныл.
\end{abstract}

Ключевые слова: древесина сосны, катализаторы $\mathrm{H}_{2} \mathrm{SO}_{4}, \mathrm{HCl}$, твердые кислотные, гидролиз, продукты, состав.

\section{Введение}

Среди древесных пород, произрастающих в России, сосна занимает около 1/6 площади всех лесов. Древесина сосны используется в химической переработке с целью получения целлюлозы и кормовых дрожжей. В гемицеллюлозах древесины сосны содержится достаточно много D-маннозы [1], имеющей высокую коммерческую привлекательность.

Манноза используется как компонент лекарственных препаратов, в терапии ряда заболеваний, связанных с повышенным уровнем сахара в крови, инфекциями, для бактериологической диагностики, исследования антивирусной активности, производства витаминов [2-5]. D-манноза значительно снижает рецидивы урологических инфекций, не уступая по эффективности антибиотикам нитрофурантоиновой группы [6, 7].

Основные способы получения D-маннозы заключаются в изомеризации других гексоз (D-фруктозы, D-глюкозы) или ее выделении непосредственно из растений [8]. Для получения маннозы обычно применяют кислотный, термический, ферментативный гидролиз пищевого сырья - кофейных зерен, апельсиновой цедры, клюквы, яблок, манго [9-13]. 
Изучение возможности получения маннозы из непищевого древесного сырья представляется весьма перспективным, поскольку содержание маннанов в древесине хвойных пород достигает $12 \%$ мас. Известно [14], что при гидротермической обработке измельченной хвойной древесины в течение 60 мин при температуре $170-180{ }^{\circ} \mathrm{C}$ можно выделить до $90 \%$ мас. содержащейся в древесине маннозы.

Имеются сведения [15] о влиянии условий процесса гидролиза гемицеллюлоз древесины сосны на выход сахаров. Высокий выход моносахаров (около 70 \% от массового содержания гемицеллюлоз в сосне) получен при температуре $150{ }^{\circ} \mathrm{C}$ в присутствии трифторуксусной кислоты. В присутствии минеральных кислот $\mathrm{HCl}, \mathrm{H}_{2} \mathrm{SO}_{4}, \mathrm{HNO}_{3}, \mathrm{H}_{3} \mathrm{PO}_{4}$ выход моносахаров не превышает $60 \%$ мас.

Серная кислота широко используется при гидролизе древесины [16-18], в том числе и при повышенных температурах [19]. Однако проведение процессов гидролиза в жестких условиях сопровождается деградацией сахаров [20].

Ранее нами была показана возможность осуществления гидролиза гемицеллюлоз древесины березы в мягких условиях - при $100{ }^{\circ} \mathrm{C}$ и атмосферном давлении в присутствии 2-3 \% мас. $\mathrm{H}_{2} \mathrm{SO}_{4}[21]$.

В последние годы возрастает интерес к исследованию процессов гидролиза гемицеллюлоз в присутствии твердых кислотных катализаторов [22-24]. Замена токсичных и коррозионноактивных минеральных кислот на твердые кислотные катализаторы позволяет повысить экологическую безопасность процесса, а также решить проблему отделения продуктов реакции от катализатора и обеспечить его многократное использование.

Для процессов гидролиза растительного сырья особый интерес представляют катализаторы на основе пористого углерода и мезопористые силикатные материалы (например, семейства SBA), которые обладают высокой удельной поверхностью (до 1000 м²/г), большим объемом пор и упорядоченной пористой структурой [25-28].

Основная сложность, связанная с гетерогенно-каталитическим гидролизом древесины, заключается в обеспечении эффективного контакта твердого катализатора с твердым реагентом. Повышение эффективности процесса гидролиза полисахаридов из древесины может быть достигнуто путем ее механической активации [29].

Целью настоящего исследования являлся подбор условий гидролиза гемицеллюлоз древесины сосны в присутствии растворенных или твердых кислотных катализаторов, обеспечивающих максимальный выход моносахаров.

\section{Экспериментальная часть}

Исходные материалы и реактивы, катализаторы

В качестве исходного сырья использовали древесные опилки (фракция 2-5 мм) сосны обыкновенной (Pinus Sylvestris L.), произрастающей в Красноярском крае. Химический состав древесины сосны (\% от массы абс. сух. древесины): целлюлоза 47,6; лигнин 28,0; гемицеллюлозы 17,0; экстрактивные вещества 7,6; зола 0,3.

Катализаторами гидролиза древесины сосны служили растворы минеральных кислот $\mathrm{H}_{2} \mathrm{SO}_{4}$ и $\mathrm{HCl}$, а также твердые кислотные катализаторы Amberlyst-15, кислотномодифицированные SBA-15 и Сибунит-4. 
Модифицирование углеродного мезопористого материала Сибунит-4 проводили, обрабатывая его сначала водным раствором азотной кислоты (35 \% об. $\mathrm{HNO}_{3}$ ), а затем дополнительно дымящейся серной кислотой по методике, изложенной в [30]. Двустадийное модифицирование мезопористого SBA-15 включало прививку 3-меркаптопропилтриметоксисилана и окисление меркаптогрупп до - $\mathrm{SO}_{3} \mathrm{H}$ с использованием 30 \% пероксида водорода [31].

Текстурные свойства модифицированных материалов были исследованы методом низкотемпературной адсорбции $\mathrm{N}_{2}$ на установке ASAP-2420 (Micrometritics, США) при T=98 К в интервале относительных давлений $\left(\mathrm{P} / \mathrm{P}^{0}\right)$ 0,06-0,99 с шагом 0,015. Удельную площадь поверхности рассчитывали по модели ВЕТ в интервале $\mathrm{P} / \mathrm{P}^{0} 0,06-0,25$, внутренний объем пор - по методу «Single Point BET», а распределение пор по размерам получали по уравнению изотермы BJH.

Концентрацию кислотных групп на поверхности катализаторов определили кислотноосновным титрованием гидроксидом натрия.

В результате прививки функциональных групп для всех образцов катализаторов наблюдается закономерное уменьшение площадей удельной поверхности и размеров пор. Некоторые характеристики катализаторов приведены в табл. 1.

Гидролиз древесины сосны в присутствии растворенных кислотных катализаторов проводили в стеклянном реакторе при атмосферном давлении, температуре $100{ }^{\circ} \mathrm{C}$, в течение $1-4$ ч при интенсивности перемешивания 14 об/с. Негидролизованный древесный остаток промывали дистиллированной водой до нейтральной реакции промывных вод и высушивали в сушильном шкафу при температуре $103^{\circ} \mathrm{C}$. Конверсию древесины определяли весовым методом с точностью $\pm 2-3 \%$.

Гидролиз древесины сосны в присутствии твердых кислотных катализаторов проводили в водной среде при температуре $110-150{ }^{\circ} \mathrm{C}$ во вращающемся стальном автоклаве с внутренней фторопластовой пробиркой объемом 35 мл, помещенном в металлический воздушный термостат. Скорость вращения автоклава составляла 11 об/мин. Смесь древесины сосны $(0,2$ г) и твердого катализатора $(0,2$ г) предварительно подвергали механической обработке в планетарной мельнице АГО-2 в течение 30 мин при центробежном ускорении мелящих тел 60 г.

Индивидуальный состав и содержание моносахаров в гидролизатах исследовали хроматографическим методом с использованием газового хроматографа «VARIAN-450 GC» с пламенно-ионизационным детектором на капиллярной колонке VF-624ms длиной 30 м, вну-

Таблица 1. Текстурные характеристики катализаторов

Table 1. Texture characteristics of the catalysts

\begin{tabular}{|l|c|c|c|c|}
\hline \multicolumn{1}{|c|}{ Катализатор } & $\mathrm{S}_{\mathrm{BEт}}, \mathrm{M}^{2} / \Gamma$ & $\mathrm{V}_{\text {пор, }} \mathrm{cm}^{3} / \Gamma$ & $\mathrm{D}_{\text {пор }}, \mathrm{Hм}$ & $\begin{array}{c}\mathrm{C}_{\text {кисл. групл, }} \\
\text { ммоль/ } /\end{array}$ \\
\hline Исходный Сибунит-4 & 379 & 0,63 & 6,6 & 0,04 \\
\hline Кислотномодифицированный Сибунит-4 & 267 & 0,36 & 5,3 & 0,48 \\
\hline Исходный SBA-15 & 550 & 0,82 & 5,9 & - \\
\hline Кислотномодифицированный SBA-15 & 417 & 0,59 & 5,6 & 0,71 \\
\hline
\end{tabular}


тренним диаметром 0,32 мм. Пробу гидролизата предварительно подвергали дериватизации по методике [32] с образованием триметилсилильных производных.

Выход моносахаров из гемицеллюлоз древесины сосны рассчитывали по аналогии с работой [33].

В качестве стандартов для анализа использовали глюкозу (Panreac, Германия), ксилозу (Panreac), маннозу (Panreac, Германия), арабинозу (Panreac, Германия), галактозу (Panreac, Германия), сорбит (Рanreac, Германия).

Содержание гемицеллюлоз и целлюлозы в древесине и лигноцеллюлозе сосны определяли по методике [34]. Определение лигнина проводили по методу Класона с использованием 72 \% $\mathrm{H}_{2} \mathrm{SO}_{4}$ [35]. Перед проведением анализов выполняли обессмоливание древесных опилок в соответствии со стандартным методом ANSI/ASTM D 1105. Для определения зольности высушенные опилки прокаливали в фарфоровом тигле в муфельной печи при температуре $(575 \pm 25){ }^{\circ} \mathrm{C}$ в течение 3-4 ч до полного удаления углерода (отсутствие черных точек), затем остужали и охлаждали в эксикаторе, взвешивали и продолжали прокаливать по 1 ч до достижения постоянной массы [36].

ИК-спектры древесины и лигниноцеллюлозных образцов снимали на ИК-Фурье спектрометре Tensor 27 (Bruker, Германия) в области 4000-400 см-1. Обработку спектральной информации проводили с использованием пакета программы OPUS, версия 5.0. Образцы для съемки ИК-спектров поглощения готовили в виде прессованных таблеток, содержащих 2 мг образца в матрице бромистого калия.

\section{Гидролиз гемищеллюлоз древесины сосны}

в присутствии растворенных катализаторов

Ранее, при изучении процесса гидролиза гемицеллюлоз древесины березы, провидимого в мягких условиях (температура $100^{\circ} \mathrm{C}$ и атмосферное давление), нами установлено [21], что выход целевого продукта (ксилозы) зависел от концентрации сернокислотного катализатора и продолжительности гидролиза. Максимальные выходы ксилозы были получены при гидролизе древесины березы 2 и $3 \%$-ной $\mathrm{H}_{2} \mathrm{SO}_{4}$.

С целью подбора оптимальных условий гидролиза гемицеллюлоз древесины сосны, обеспечивающих максимальный выход моносахаров, изучено влияние природы катализаторов и условий гидролиза на конверсию древесины сосны и выход моносахаров из гемицеллюлоз при температуре $100^{\circ} \mathrm{C}$. Обнаружено, что при аналогичных условиях гидролиза степень конверсии древесины сосны в присутствии серной кислоты ниже, чем при использовании соляной кислоты, и составляет 17-23 и 20-28 \% мас. соответственно (рис. 1).

Максимальный выход моносахаров (94,0-96,0 \% мас.) достигается в присутствии катализатора $2 \%$ мас. $\mathrm{HCl}$ и продолжительности гидролиза 2-4 ч. При использовании катализатора $2 \%$ мас. $\mathrm{H}_{2} \mathrm{SO}_{4}$, максимальный выход моносахаров в аналогичных условиях составляет $90 \%$ мас.

Влияние гидромодуля на конверсию древесины сосны и выход моносахаров в присутствии $\mathrm{H}_{2} \mathrm{SO}_{4}$ иллюстрируются рис. 2.

Повышение гидромодуля процесса гидролиза с 8 до 15 увеличивает конверсию древесины до 20,5 \% мас., а выход моносахаров из гемицеллюлоз - до 63 \% мас. (рис. 2). Дальнейшее по- 


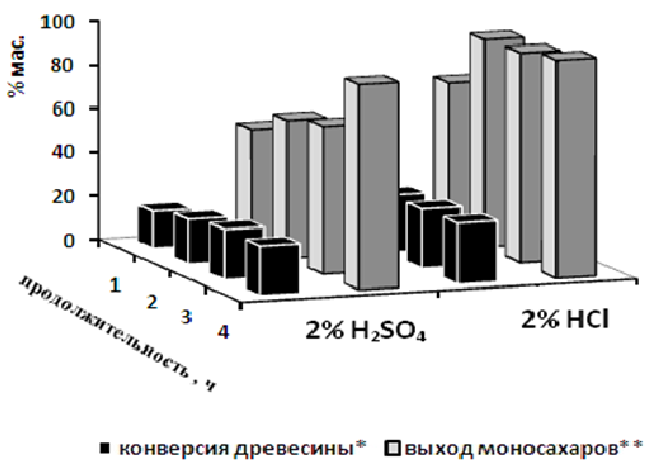

*от массы абс. сух. древесины, ** от исходного содержания гемицеллюлоз в сосне

Рис. 1. Влияние растворенных кислотных катализаторов и продолжительности гидролиза древесины сосны на ее конверсию и выход моносахаров при температуре $100{ }^{\circ} \mathrm{C}$ и гидромодуле 15

Fig. 1. Effect of dissolved acid catalysts and the reaction time of pine wood hydrolysis on its conversion and on the yield of monosaccharides at $100{ }^{\circ} \mathrm{C}$ and hydromodule 15

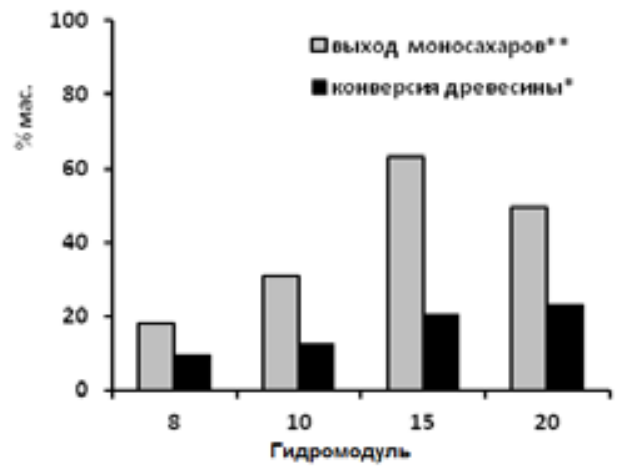

*от массы абс. сух. древесины, ** от исходного содержания гемицеллюлоз в сосне

Рис. 2. Влияние величины гидромодуля процесса гидролиза древесины сосны на ее конверсию и выход моносахаров при температуре $100{ }^{\circ} \mathrm{C}$ (катализатор $2 \%$ мас. $\mathrm{H}_{2} \mathrm{SO}_{4}$, продолжительность 2 ч)

Fig. 2. Effect of the hydromodule value of the pine wood hydrolysis on conversion of the wood and yield of monosaccharides at $100{ }^{\circ} \mathrm{C}$ (catalyst $2 \%$ wt. $\mathrm{H}_{2} \mathrm{SO}_{4}$, time $2 \mathrm{~h}$ )

вышение гидромодуля до 20 незначительно влияет на конверсию древесины. Однако при этом заметно снижается выход моносахаров (до 50 \% мас.), что, вероятно, связано с протеканием дальнейших превращений моносахаров, включая реакции образования гуминовых веществ. Таким образом, оптимальная величина гидромодуля в процессе гидролиза древесины сосны при 100 ㄷ в присутствии растворенных кислотных катализаторов составляет 15 .

Методом газовой хроматографии изучен состав гидролизатов, полученных из древесины сосны с использованием сернокислотного и солянокислотного катализаторов.

В качестве примера на рис. 3 приведена газовая хроматограмма гидролизата, полученного гидролизом гемицеллюлоз древесины сосны при $100{ }^{\circ} \mathrm{C}$ в присутствии катализатора 2 \% мас. $\mathrm{HCl}$.

Максимальное содержание наиболее ценного моносахарида маннозы (5,6 г/л) обнаружено в гидролизате, полученном из древесины сосны в присутствии 2 \% мас. $\mathrm{HCl}$ (рис. 4Б). Наряду с 


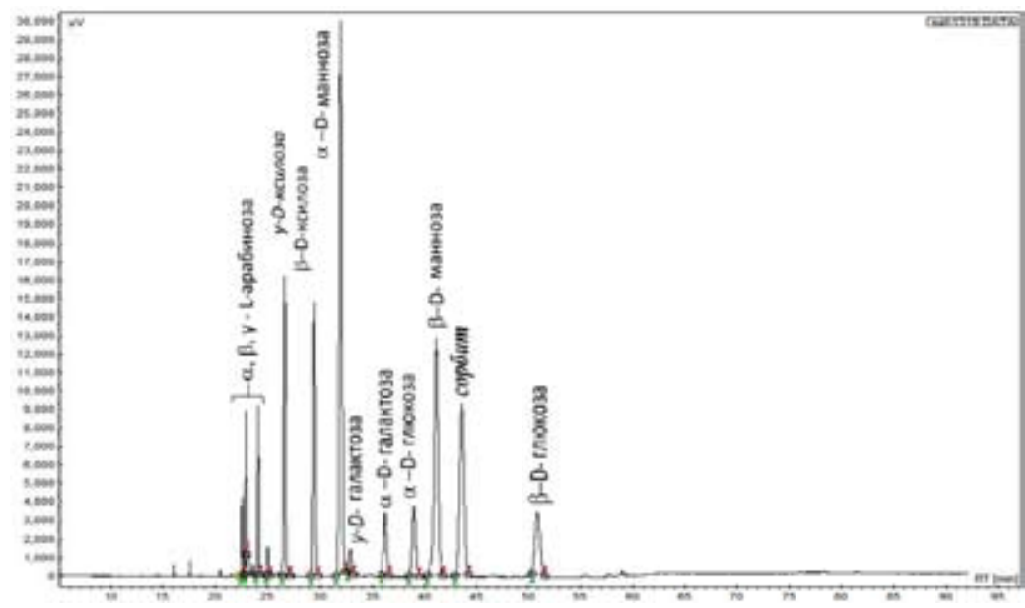

Рис. 3. Хроматограмма гидролизата, полученного гидролизом гемицеллюлоз древесины сосны при температуре $100{ }^{\circ} \mathrm{C}$, гидромодуле 15 и продолжительности 4 ч (катализатор $2 \% \mathrm{Mac.} \mathrm{HCl}$, сорбит внутренний стандарт)

Fig. 3. Chromatogram of hydrolyzate obtained by hydrolysis of pine wood hemicelluloses at $100{ }^{\circ} \mathrm{C}$, hydromodule 15 and time 4 h (catalyst $2 \% \mathrm{wt}$. $\mathrm{HCl}$, sorbitol - internal standard)

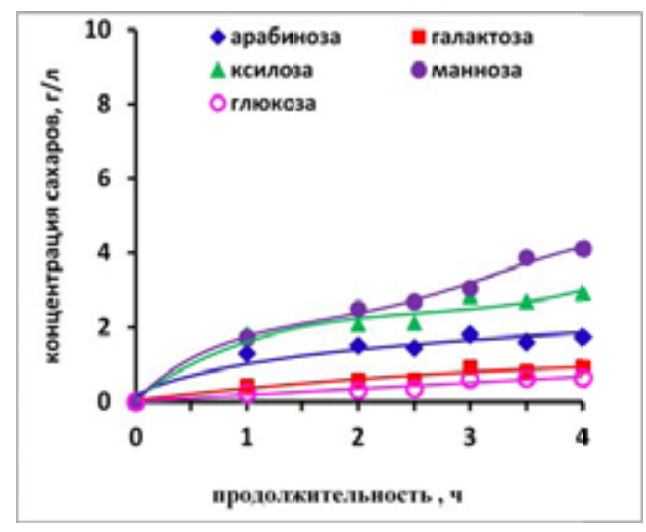

A

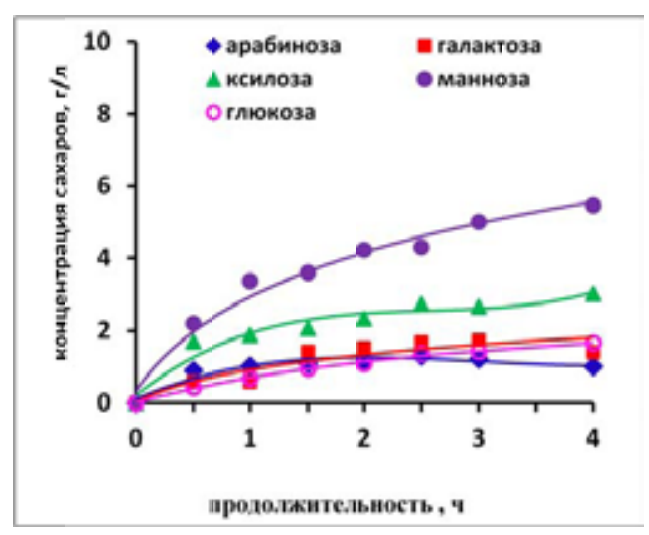

Б

Рис. 4. Влияние продолжительности гидролиза древесины сосны при температуре $100{ }^{\circ} \mathrm{C}$ и гидромодуле 15 на содержание моносахаров в гидролизатах: А - катализатор 2 \% мас. $\mathrm{H}_{2} \mathrm{SO}_{4}$, Б - катализатор $2 \%$ $\mathrm{HCl}$

Fig. 4. Effect of reaction time of the pine wood hydrolysis at $100{ }^{\circ} \mathrm{C}$ and hydromodule 15 on the content of monosaccharides in hydrolysates: A - catalyst $2 \%$ wt. $\mathrm{H}_{2} \mathrm{SO}_{4}, \mathrm{~B}$ - catalyst $2 \%$ wt. $\mathrm{HCl}$

маннозой (составляет около 50 \% от массы гемицеллюлоз), в гидролизате присутствует ксилоза ( 24 \% мас.), арабиноза ( 5 \% мас.), галактоза ( 8 \% мас.) и глюкоза ( 9 \% мас.).

Концентрация арабинозы в гидролизатах, полученных в присутствии соляной кислоты, ниже по сравнению с гидролизатами, полученными при использовании сернокислотного катализатора (1,2 и 1,8 г/л соответственно). Установлено, что арабиноза в присутствии соляной кислоты подвергается вторичным превращениям с образованием фурфурола (до 0,5 г/л). Это согласуется с литературными данными [37]. 
Концентрация других моносахаров (ксилозы, галактозы, глюкозы) в составе гидролизатов повышается с увеличением продолжительности гидролиза гемицеллюлоз древесины сосны (рис. 4А и Б). Глюкоза является продуктом гидролиза не только гемицеллюлоз, но и легкогидролизуемой части целлюлозы древесины сосны. Манноза также может образовываться в результате каталитической эпимеризации глюкозы [38].

В табл. 2 приведены данные химического анализа твердых лигноцеллюлозных продуктов гидролиза древесины сосны. В выбранных условиях процесса наиболее интенсивно протекает гидролиз гемицеллюлоз. Причем активность катализатора 2 \% мас. $\mathrm{HCl}$ в гидролизе гемицеллюлоз выше, чем сернокислотного катализатора. В присутствии солянокислотного катализатора содержание гемицеллюлоз в лигноцеллюлозном продукте снижается до 2,6 \% мас. при продолжительности гидролиза 2 ч.

Содержание целлюлозы и лигнина в лигноцеллюлозных продуктах возрастает с увеличением продолжительности процесса гидролиза, что обусловлено удалением гемицеллюлоз из древесины. Кроме того, увеличение содержания лигнина в лигноцеллюлозном продукте может быть связано с образованием лигноподобных веществ (так называемого псевдолигнина) [39] в результате вторичных превращений моносахаров.

В ИК-спектрах древесины сосны и лигноцеллюлозных продуктов, полученных гидролизом гемицеллюлоз древесины в присутствии $2 \%$ мас. $\mathrm{H}_{2} \mathrm{SO}_{4}$ и $2 \%$ мас. $\mathrm{HCl}$, присутствуют характеристические полосы поглощения целлюлозы в области 3600-3000, 3000-2700, 1500-1300, 1200-1000 см с $^{-1}$ рис. 5). Они соответствуют валентным колебаниям связей $-\mathrm{OH}$ и $-\mathrm{CH},-\mathrm{CH}_{2}$ и деформационным и валентным колебаниям связей $\mathrm{CO}$ и $\mathrm{C}-\mathrm{O}-\mathrm{C}$ глюкопиранозного кольца $[40,41]$.

Широкая полоса поглощения в области 3600-3100 см-1 ИК-спектров древесины и лигноцеллюлозы сосны обусловлена валентными колебаниями гидроксильных групп, вовлеченных

Таблица 2. Влияние природы кислотных катализаторов на состав лигноцеллюлозных продуктов гидролиза древесины сосны при температуре $100^{\circ} \mathrm{C}$

Table 2. Influence of the nature of acid catalysts on the composition of lignocellulosic products of pine wood hydrolysis at $100^{\circ} \mathrm{C}$

\begin{tabular}{|c|c|c|c|c|}
\hline \multirow[t]{2}{*}{ Образец } & \multirow{2}{*}{$\begin{array}{c}\text { Продолжительность } \\
\text { гидролиза, ч }\end{array}$} & \multicolumn{3}{|c|}{$\begin{array}{l}\text { Содержание основных компонентов в } \\
\text { лигноцеллюлозном продукте, \% мас }\end{array}$} \\
\hline & & целлюлоза & лигнин & гемицеллюлозы \\
\hline Исходная древесина сосны* & отсутствует & 47,6 & 28,0 & 17,0 \\
\hline \multirow{4}{*}{$\begin{array}{l}\text { Древесина сосны после } \\
\text { гидролиза } 2 \% \mathrm{H}_{2} \mathrm{SO}_{4}{ }^{* *}\end{array}$} & 1 & 51,1 & 29,2 & 11,7 \\
\hline & 2 & 52,4 & 30,8 & 9,4 \\
\hline & 3 & 53,0 & 33,0 & 7,2 \\
\hline & 4 & 54,0 & 35,5 & 4,5 \\
\hline \multirow{4}{*}{$\begin{array}{l}\text { Древесина сосны после } \\
\text { гидролиза } 2 \text { \% } \mathrm{HCl}^{* *}\end{array}$} & 1 & 51,2 & 31,8 & 10,0 \\
\hline & 2 & 52,8 & 33,0 & 2,6 \\
\hline & 3 & 54,4 & 34,6 & 2,0 \\
\hline & 4 & 55,5 & 36,7 & 1,8 \\
\hline
\end{tabular}

*- от массы абсолютно сухой древесины; **-от абсолютно сухого лигноцеллюлозного продукта. 


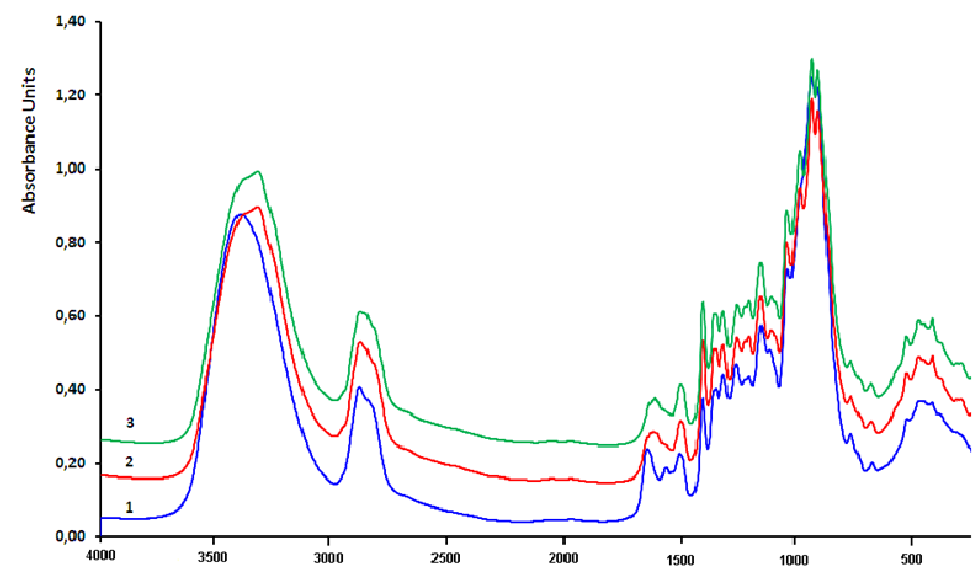

Рис. 5. ИК-спектры древесины (1) и лигноцеллюлозных продуктов, полученных из древесины сосны гидролизом $2 \%$ мас. $\mathrm{H}_{2} \mathrm{SO}_{4}(2)$ и $2 \%$ мас. $\mathrm{HCl}(3)$ при температуре $100{ }^{\circ} \mathrm{C}$ в течение 4 ч

Fig. 5. IR spectra of wood (1) and lignocellulosic products obtained from pine wood by hydrolysis of $2 \% \mathrm{wt}$. $\mathrm{H}_{2} \mathrm{SO}_{4}(2)$ and $2 \%$ wt. $\mathrm{HCl}(3)$ at $100{ }^{\circ} \mathrm{C}$ and during $4 \mathrm{~h}$

в водородные связи. В спектрах лигноцеллюлозных продуктов наблюдается снижение интенсивности этих полос поглощения и их смещение в область низких частот, что свидетельствует о снижении в твердых продуктах гидролиза древесины количества гидроксильных групп, участвующих в образовании межмолекулярных водородных связей.

Древесина сосны содержит, помимо целлюлозы, также гемицеллюлозы и лигнин. О наличии гемицеллюлоз свидетельствует интенсивная полоса поглощения при $1730 \mathrm{~cm}^{-1}$ в ИК-спектре исходной древесины сосны, характерная для карбонильных групп гемицеллюлоз [41, 42]. В лигноцеллюлозном продукте, полученном гидролизом древесины сосны в присутствии серной или соляной кислот, интенсивность этой полосы заметно меньше, чем в древесине, что свидетельствует о снижении количества гемицеллюлоз в процессе каталитического гидролиза древесины.

В ИК-спектрах древесины и лигноцеллюлозных продуктов присутствуют полосы поглощения фенилпропановых структур лигнина в областях 1620-1590, 1525-1495, 1475-1450 см-1 и полосы поглощения при 1612 и $1516 \mathrm{~cm}^{-1}$ (рис. 5).

\section{Гидролиз гемицеллюлоз древесины сосны}

\section{в присутствии твердых кислотных катализаторов}

Каталитическая активность твердых кислотных катализаторов Amberlyst-15, модифицированных Сибунита-4 и SBA-15 в гидролизе гемицеллюлоз древесины сосны исследована при температурах $110-150{ }^{\circ} \mathrm{C}$. Для улучшения контакта твердого катализатора с твердым реагентом - опилками древесины сосны, их подвергали механической обработке в мельнице АГО-2.

Установлено, что предварительная механическая обработка древесины сосны повышает выход моносахаров в процессе гидролиза активированной древесины при $150{ }^{\circ} \mathrm{C}$ как в присутствии катализатора Amberlyst-15, так и в отсутствие его (табл. 3).

В выбранных условиях (табл. 3) катализатор Amberlyst-15 увеличивает выход моносахаров с 22,1 до 45,2 \% мас. в процессе гидролиза неактивированной древесины сосны и с 33,8 до 88,2 \% мас. при гидролизе мехобработанной древесины.

$$
-50-
$$


Максимальный выход моносахаров (93 \% мас.) из гемицеллюлоз активированной древесины сосны получен в течение 3 ч в присутствии кислотно-модифицированного катализатора SBA-15 при температуре $150{ }^{\circ} \mathrm{C}$ и продолжительности гидролиза 3 ч (рис. 6).

При температуре гидролиза древесины $130{ }^{\circ} \mathrm{C}$ высокий выход моносахаров в присутствии катализаторов Amberlyst-15 (80 \% мас.) и кислотно-модифицированного SBA-15 (62 \% мас.)

Таблица 3. Влияние механической обработки древесины сосны на выход моносахаров в процессе гидролиза при температуре $150{ }^{\circ} \mathrm{C}$ и продолжительности 2 ч

Table 3. Influence of mechanical treatment of pine wood on the yield of monosaccharides during hydrolysis at $150{ }^{\circ} \mathrm{C}$ and time $2 \mathrm{~h}$

\begin{tabular}{|l|c|}
\hline \multicolumn{1}{|c|}{ Сырье, катализатор } & $\begin{array}{c}\text { Выход } \\
\text { моносахаров, \% мас.* }\end{array}$ \\
\hline Исходная древесины сосны (фр. 2-5 мм), без катализатора & 22,1 \\
\hline Активированная в АГО-2 древесина сосны, без катализатора (фр. 0,1-0,25 мм) & 33,8 \\
\hline Смесь исходной древесины сосны (фр. 2-5 мм) и катализатора Amberlyst-15 & 45,2 \\
\hline $\begin{array}{l}\text { Смесь активированной в АГО-2 древесины сосны и катализатора Amberlyst-15 } \\
\text { (фр. 0,1-0,25 мм) }\end{array}$ & 88,2 \\
\hline
\end{tabular}

* от исходного содержания гемицеллюлоз.
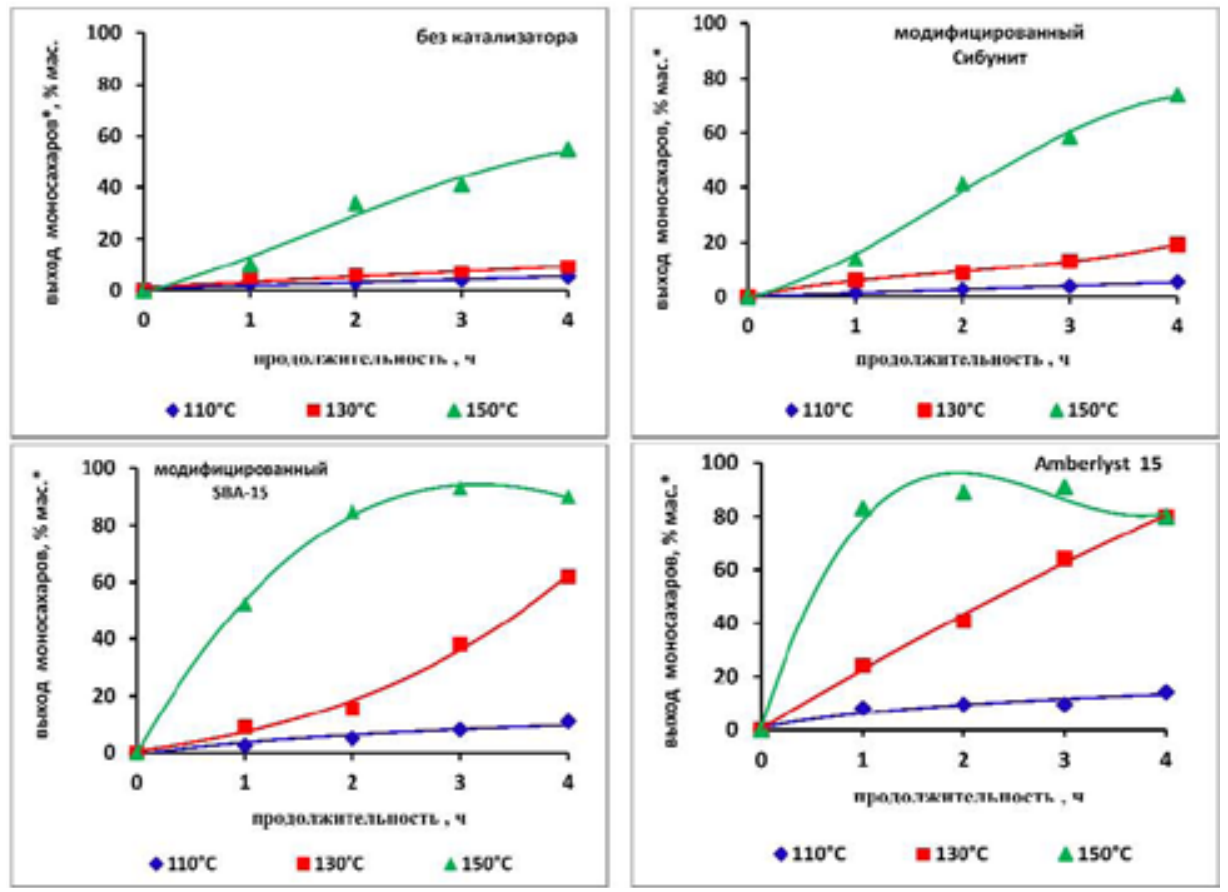

* от исходного содержания гемицеллюлоз

Рис. 6. Влияние температуры и продолжительности гидролиза гемицеллюлоз древесины сосны в присутствии твердых кислотных катализаторов на выход моносахаров

Fig. 6. Influence of the temperature and time of hydrolysis of pine wood hemicelluloses in the presence of solid acid catalysts on the yield of monosaccharides 
Таблица 4. Влияние условий гидролиза гемицеллюлоз древесины сосны на суммарный выход моносахаров и выход маннозы в присутствии растворенных и твердых кислотных катализаторов

Table 4. Influence of conditions of hydrolysis of pine wood hemicelluloses on the total yield of monosaccharides and on the yield of mannose in the presence of dissolved and solid acid catalysts

\begin{tabular}{|c|c|c|c|c|}
\hline \multicolumn{2}{|c|}{ Условия гидролиза древесины сосны } & $\begin{array}{c}\text { Суммарный выход } \\
\text { моносахаров, } \\
\text { \% мас.* }\end{array}$ & $\begin{array}{c}\text { Выход маннозы, } \\
\% \text { мас.* }\end{array}$ \\
\hline катализатор & температура, ${ }^{\circ} \mathrm{C}$ & продолжительность, ч & 96,0 & 50,0 \\
$\mathrm{HBA}-15$ & 100 & 4 & 93,0 & 40,0 \\
$\mathrm{Amberlyst-15}$ & 150 & 3 & 91,2 & 45,0 \\
$\mathrm{H}_{2} \mathrm{SO}_{4}$ & 150 & 3 & 90,0 & 37,0 \\
Сибунит-4 & 100 & 4 & 73,7 & 19,0 \\
без катализатора & 150 & 4 & 55,0 & 12,0 \\
\hline
\end{tabular}

* от исходного содержания гемицеллюлоз в сосне.

достигается при продолжительности процесса 4 ч. Вероятно, пониженная каталитическая активность Сибунита в гидролизе гемицеллюлоз древесины сосны объясняется невысоким содержанием кислотных групп в его составе и меньшей площадью удельной поверхности, по сравнению с катализатором SBA-15 (табл. 1).

В составе гидролизатов из активированной древесины сосны, полученных при температуре $150{ }^{\circ} \mathrm{C}$ в присутствии катализаторов Amberlyst-15 и SBA-15, в значительном количестве содержится манноза. Гидролизаты, полученные некаталитическим гидролизом и гидролизом в присутствии катализатора Сибунит, отличаются более высоким содержанием арабинозы, ксилозы и галактозы.

В гидролизатах, полученных в присутствии катализатора Amberlyst-15 при температуpe $150{ }^{\circ} \mathrm{C}$ и продолжительности гидролиза 4 ч, зафиксировано образование фурфурола $(0,5-$ 0,7 г/л) и 5-гидроксиметилфурфурола (0,1-0,2 г/л).

При сопоставлении кталитических свойств растворенных и твердых кислотных катализаторов в гидролизе древесины сосны (табл. 4) установлено, что выход моносахаров снижается в следующем ряду катализаторов: $\mathrm{HCl}\left(100^{\circ} \mathrm{C}, 4\right.$ ч) $>\mathrm{SBA}-15\left(150^{\circ} \mathrm{C}, 3\right.$ ч) > Amberlyst-15 $\left(150^{\circ} \mathrm{C}\right.$, 3 ч) $>\mathrm{H}_{2} \mathrm{SO}_{4}\left(100{ }^{\circ} \mathrm{C}, 4\right.$ ч) $>$ Сибунит $-4\left(150{ }^{\circ} \mathrm{C}, 4\right.$ ч) $>$ без катализатора $\left(150{ }^{\circ} \mathrm{C}, 4\right.$ ч).

Максимальный выход наиболее коммерчески востребованного моносахарида маннозы достигнут в процессах гидролиза гемицеллюлоз древесины сосны в присутствии катализаторов $\mathrm{HCl}$ при $100{ }^{\circ} \mathrm{C}\left(50 \%\right.$ мас.) и Amberlist-15 при $150{ }^{\circ} \mathrm{C}(45 \%$ мас.).

Твердые лигноцеллюлозные продукты, остающиеся после гидролиза гемицеллюлоз древесины сосны, содержат 51,0-55,5 \% мас. целлюлозы.

\section{Заключение}

Сопоставлена активность растворенных $\left(\mathrm{H}_{2} \mathrm{SO}_{4}, \mathrm{HCl}\right)$ и твердых кислотных катализаторов (ионообменной смолы Amberlyst-15, кислотно-модифицированных SBA-15, Сибунит-4) в гидролизе гемицеллюлоз древесины сосны при температурах $100-150{ }^{\circ} \mathrm{C}$. Установлено, что выход моносахаров снижается с 96 до $55 \%$ мас. в ряду катализаторов: $\mathrm{HCl}\left(100{ }^{\circ} \mathrm{C}, 4\right.$ ч) > SBA-15

$$
-52-
$$


$\left(150{ }^{\circ} \mathrm{C}, 3\right.$ ч) $>$ Amberlyst-15 $\left(150{ }^{\circ} \mathrm{C}, 3\right.$ ч $)>\mathrm{H}_{2} \mathrm{SO}_{4}\left(100^{\circ} \mathrm{C}, 4\right.$ ч) $>$ Сибунит $-4\left(150{ }^{\circ} \mathrm{C}, 4\right.$ ч) $>$ без катализатора $\left(150^{\circ} \mathrm{C}, 4\right.$ ч). Гидролизаты с максимальным содержанием востребованной $\mathrm{D}-$ маннозы получены гидролизом древесины сосны в присутствии $2 \%$ мас. $\mathrm{HCl}$ при $100{ }^{\circ} \mathrm{C}(50 \%$ мас.) и Amberlyst-15 при $150{ }^{\circ} \mathrm{C}$ (45 \% мас.). Лигноцеллюлозный остаток гидролиза гемицеллюлоз древесины сосны содержит до 55,5 \% мас. целлюлозы и может быть использован для переработки в качественную целлюлозу или в биоэтанол.

\section{Список литературы}

1. Sjostrom E. Wood Chemistry. Fundamentals and Applications. Second edition. San Diego: Academic press, 1993. 292 p.

2. Aguedo M., Kohnen S., Rabetafika N., Bossche S.V., Sterckx J., Blecker C., Beauve C., Paquot M. Composition of by-products from cooked fruit processing and potential use in food products. J Food Comp Anal. 2012. Vol. 27, P. 61-69.

3. Ranta K., Nieminen K., Ekholm F.S., Pol'akov'a M., Roslund M.U., Saloranta T., Leino R., Savolainen J. Evaluation of immunostimulatory activities of synthetic mannose-containing structures mimicking the $\beta$-(1 $\rightarrow 2)$-linked cell wall mannans of Candida albicans. Clin Vaccine Immunol. 2012. Vol. 19, P. 1889-1893.

4. Mishra D.K., Hwang J.S. Selective hydrogenation of D-mannose to D-mannitol using NiOmodified $\mathrm{TiO}_{2}\left(\mathrm{NiO}-\mathrm{TiO}_{2}\right)$ supported ruthenium catalyst. Appl Catal. 2013. 453, P. 13-19.

5. Chen F.E., Zhao J.F., Xiong F.J., Xie B., Zhang P. An improved synthesis of a key intermediate for (+)-biotin from d-mannose. Carbohyd Res. 2007. Vol. 342, P. 2461-2464.

6. Hu X., Shi Y., Zhang P., Miao M., Zhang T., Jiang B. D-Mannose: Properties, production, and applications: An overview. Comprehensive Reviews in Food Science and Food Safety. 2016. Vol. 15, P. 773-785.

7. Kranj`cec B., Pape`s D., Altarac S. D-mannose powder for prophylaxis of recurrent urinary tract infections in women: a randomized clinical trial. World J Urol. 2014. Vol. 32, P. 79-84.

8. Hirose J., Kinoshita Y., Fukuyama S., Hayashi S., Yokoi H., Takasaki Y. Continuous isomerization of D-fructose to D-mannose by immobilized Agrobacterium radiobacter cells. Biotechnology Letters. 2003. Vol. 25(4), P. 349-352.

9. Patent 20,130,061,848 US. Kenny F.J.S., Fernandes J.A., Leclerc V. Coffee treatment method. Publ. Date 2013.

10. Mussatto S.I., Carneiro L.M., Silva J.P.A., Roberto I.C., Teixeira J.A. A study on chemical constituents and sugars extraction from spent coffee grounds. Carbohyd Polym. 2011. Vol. 83, P. 368374.

11. Safarik I., Horska K., Svobodova B., Safarikova M. Magnetically modified spent coffee grounds for dyes removal. Eur Food Res Technol. 2012. Vol. 234, P. 345-350.

12. Johnson-White B., Buquo L., Zeinali M., Ligler F.S. Prevention of nonspecific bacterial cell adhesion in immunoassays by use of cranberry juice. Anal Chem. 2006. Vol. 78, P. 853-857.

13. Yashoda H.M., Prabha T.N., Tharanathan R.N. Mango ripening-role of carbohydrates in tissue softening. Food Chem. 2007. Vol. 102, P. 691-698.

14. Hannuksela T., Fardim P., Holmbom B. Sorption of spruce O-acetylated galactoglucomannans onto different pulp fibres. Cellulose. 2003. Vol. 10, P. 317-324. 
15. Marzialetti T., Valenzuela Olarte M.B, Sievers C., Hoskins T.J.C., Agrawal P.K., Jones Ch.W. Dilute acid hydrolysis of loblolly Pine: A comprehensive approach. Ind. Eng. Chem. Res. 2008. Vol. 47, P. 7131-7140.

16. Arora A., Carrier D.J. Understanding the pine dilute acid pretreatment system for enhanced enzymatic hydrolysis. ACS Sustainable Chem. Eng. 2015. Vol. 3(10), P. 2423-2428.

17. Zhang T., Pan Z., Qian Ch., Chen X. Isolation and purification of D-mannose from palm kernel. Carbohydrate Research. 2009. Vol. 344, P. 1687-1689.

18. Mäki-Arvela P., Salmi T., Holmbom B., Willför S., Murzin D.Yu. Synthesis of rare sugars by hydrolysis of hemicelluloses - a review. Chemical Reviews. 2011. Vol. 111, P. 5638-5666.

19. Reyes P., Mendonça R.T., Aguayo M.G., Rodríguez J., Vega B., Fardim P. Extraction and characterization of hemicelluloses from Pinus radiata and its feasibility for bioethanol production. Revista Árvore, Viçosa-MG. 2013. Vol. 37(1), P. 175-180.

20. Klinke H.B., Thomsen A.B., Ahring B.K. Inhibition of ethanol-producing yeast and bacteria by degradation products produced during pre-treatment of biomass. Applied microbiology and biotechnology. 2004. Vol. 66(1), P. 10-26.

21. Яценкова О.В., Чудина А.И., Скрипников А.М., Чесноков Н.В., Кузнецов Б.Н. Влияние концентрации сернокислотного катализатора на гидролиз гемицеллюлоз древесины березы. Журнал Сибирского федерального университета. Химия. 2015. Т. 8(2), С. 211-221. [Yatsenkova O.V., Chudina A.I., Skripnikov A.M., Chesnokov N.V., Kuznetsov B.N. The Influence of sulfuric acid catalyst concentration on hydrolysis of birch wood hemicelluloses. Journal of Siberian Federal University. Chemistry. 2015. Vol. 8(2), P. 211-221. (In Russ.)]

22. Takagaki A., Nishimura M., Nishimura S. et al. Hydrolysis of sugars using magnetic silica nanoparticles with sulfonic acid groups. Chem. Lett. 2011. Vol. 40, P. 1195-1197.

23. Cara P.D., Pagliaro M., Elmekawy A., Brown D.R., Verschuren P., Shiju N.R., Rothenberg G. Hemicellulose hydrolysis catalysed by solid acids. Catal. Sci. Technol. 2013. Vol. 3, P. 20572061.

24. Dhepe P.L., Sahu R. A solid-acid-based process for the conversion of hemicellulose. Green Chem. 2010. Vol. 12, P. 2153-2156.

25. Suganuma S., Nakajima K., Kitano M. et al. Hydrolysis of cellulose by amorphous carbon bearing $\mathrm{SO}_{3} \mathrm{H}, \mathrm{COOH}$ and $\mathrm{OH}$ groups. J. Am. Chem. Soc. 2008. Vol. 130, P. 12787-12793.

26. Pang J., Wang A., Zheng M., Zhang T. Hydrolysis of cellulose into glucose over carbons sulfonated at elevated temperatures. Chem. Commun. 2010. Vol. 46, P. 6935-6937.

27. Degirmenci V., Uner D., Cinlar B. et al. Sulfated zirconia modified SBA-15 catalysts for cellobiose hydrolysis. Catalysis Letters. 2011. Vol. 141, P. 33-42.

28. Takagaki A., Nishimura M., Nishimura S. et al. Hydrolysis of sugars using magnetic silica nanoparticles with sulfonic acid groups. Chem. Lett. 2011. Vol. 40, P. 1195-1197.

29. Gromav N.V., Taran O.P., Sorokina K.N., Mishchenko T.I., Uthandi S., Parmon V.N. New methods for one-pot processing of polysaccherides components (cellulose and hemicellulose) of lignicellulosic biomass into valuable products. Part 1: Methods of biomass activation. Ctalysis in Industry. 2016. Vol. 8(2), P. 176-186.

30. Pang J., Wang A., Zheng M., Zhang T. Hydrolysis of cellulose into glucose over carbons sulfonated at elevated temperatures. Chem. Commun. 2010. Vol. 46, P. 6935-6937. 
31. Song S.-W., Hidajat K. and Kawi S. Functionalized SBA-15 materials as carriers for controlled drug delivery: Influence of surface properties on matrix-drug interactions. Langmuir. 2005. Vol. 21(21), P. 9568-9575.

32. Ruiz-Matute A.I., Hernandez-Hernandez O., Rodriguez-Sanchez S., Sanz M.L., MartinezCastro I. Derivatization of carbohydrates for GC and GC-MS analyses. J. Chromatogr. B. 2011. Vol. 879, P. 1226-1240.

33. Кузнецов Б.Н., Чесноков Н.В., Яценкова О.В., Судакова И.Г., Скрипников А.М., Береговцова Н.Г., Шарыпов В.И. Разработка методов получения качественных гидролизатов, основанных на интеграции каталитических процессов пероксидной делигнификации и кислотного гидролиза древесины березы. Катализ в промышленности. 2017. Т. 17(6), С. 543-553. [Kuznetsov B.N., Chesnokov N.V., Yatsenkova O.V., Sudakova I.G., Skripnikov A.M., Beregovtsova N.G., Sharypov V.I. Development of methods for obtaining qualitative hydrolysates based on integration of catalytic processes of peroxide delignification and acid hydrolysis of birch wood. Catalysis in industry. Vol. 17(6), P. 543-553. (In Russ.)]

34. Tappi, 2009. Carbohydrate composition of extractive-free wood and wood pulp by gas-liquid chromatography (Reaffirmation of T $249 \mathrm{~cm}-09$ ).

35. Tappi, 2006. Acid-insoluble lignin in wood and pulp (Reaffirmation of T $222 \mathrm{om}-02$ ).

36. Tappi, 2002. Ash in wood, pulp, paper and paperboard: combustion at $525^{\circ} \mathrm{C}$ (Reaffirmation of T 211 om-02).

37. Herrera R., Thomas da Silva D., Liano-Ponte R., Labidi J. Characterization of pine wood liquid and solid residues generated during industrial hydrothermal treatment. Biomass and Bioenergy. 2016. Vol. 95, P. 174-181.

38. Delidovich I., Palkovits R. Catalytic Isomerization of biomass-derived aldoses: A review. ChemSusChem. 2016. Vol. 9(6), P. 541-655.

39. Кузнецова С.А., Александрова Н.Б., Кузнецов Б.Н. Состав и превращения основных компонентов автогидролизованной древесины сосны, ели и осины. Химия в интересах устойчивого развития. 2001. Т. 9(5), С. 655-665. [Kuznetsova S.A., Alexandrova N.B., Kuznetsov B.N. Composition and transformation of the main components of auto-hydrolyzed pine, spruce and aspen wood. Chemistry for Sustainable Development. 2001. Vol. 9(5), P. 655-665. (in Russ.)]

40. Hinterstoisser B., Salmén L. Two-dimensional step-scan FTIR: a tool to unravel the $\mathrm{OH}$ valencyrange of the spectrum of Cellulose I. Cellulose. 1999. Vol. 6(3), P. 251-263.

41. Feng Xu, Jianming Yu, Tesfaye Tesso, Floyd Dowel, Donghai Wang. Qualitative and quantitative analysis of lignocellulosic biomass using infrared techniques: A mini-review. Applied Energy. 2013. Vol. 104, P. 801-809.

42. Fan M., Dai D., Huang B. Fourier Transform Infrared Spectroscopy for Natural Fibres. Fourier Transform - Materials Analysis, Dr. S.M. Salih (Ed). ISBN: 978-953-51-0594-7, 2012. 